\title{
Interferon- $\alpha$ suppresses invasion and enhances cisplatin-mediated apoptosis and autophagy in human osteosarcoma cells
}

\author{
JUN ZHAO ${ }^{1,2}$, MINGLI WANG ${ }^{2}$, ZENG LI $^{2}$, JINGXIAN CHEN ${ }^{3}$, ZONGSHEN YIN $^{4}$, \\ JUN $\mathrm{CHANG}^{4}$, DONGMEI GAO ${ }^{5}$ and SHIPING WANG ${ }^{1}$ \\ ${ }^{1}$ Department of Parasitology, Xiangya Medical School, Central South University, Changsha, Hunan 410078; \\ ${ }^{2}$ Department of Microbiology, Anhui Medical University, Hefei, Anhui 230032, P.R. China; \\ ${ }^{3}$ Department of Pathology and Cell Biology, Columbia University, New York, NY 10032, USA; ${ }^{4}$ Department of Orthopedics, \\ The First Affiliated Hospital of Anhui Medical University; ${ }^{5}$ Department of Clinical Laboratory, \\ The Third Affiliated Hospital of Anhui Medical University, Hefei, Anhui 230032, P.R. China
}

Received March 27, 2013; Accepted October 14, 2013

DOI: $10.3892 / \mathrm{ol} .2013 .1762$

\begin{abstract}
Interferon (IFN)- $\alpha$ is generated in response to viral infections and is used clinically in the therapy of a variety of viral infections and cancers. The present study investigated whether IFN- $\alpha$ could inhibit the invasive ability of osteosarcoma cells using a Matrigel invasion assay. In addition, the osteosarcoma cells were treated with cisplatin and/or IFN- $\alpha$. Apoptosis and autophagy were assessed using 3-(4,5-dimethylthiazol-2-yl)-2,5-diphenyltetrazolium bromide assay, Hoechst 33258 staining, flow cytometry assay, acridine orange staining, green fluorescent protein-LC3 dot assay and transmission electron microscopy. Further analysis revealed that the efficacy of cisplatin was enhanced by the addition of the cytokine, IFN- $\alpha$. These results indicate that the combination therapy of chemotherapeutics and IFN- $\alpha$ is a new approach for osteosarcoma, which requires validation by experiments in vivo.
\end{abstract}

\section{Introduction}

Interferon (IFN)- $\alpha$ is a member of the type I interferon family, which is active as an antiviral and immunomodulatory cytokine. Type I IFNs are able to modulate a variety of cellular responses, including cell growth and apoptosis. In humans, the production of IFN- $\alpha$ is most efficiently induced in numerous

Correspondence to: Professor Shiping Wang, Department of Parasitology, Xiangya Medical School, Central South University, 110 Xiangya Road, Changsha, Hunan 410078, P.R. China

E-mail: spwang@126.com

Professor Mingli Wang, Department of Microbiology, Anhui Medical University, 69 Meishan Road, Hefei, Anhui 230032, P.R. China

E-mail anhuiweishengwu@yahoo.com.cn

Key words: interferon- $\alpha$, apoptosis, autophagy, osteosarcoma cell, cisplatin types of immune cells by viral infection $(1,2)$. IFN- $\alpha$ has been used clinically in the therapy of certain malignancies and viral diseases. Although the antitumor mechanism of IFN- $\alpha$ is not entirely understood, cell cycle arrest and apoptosis have been shown to be involved. These effects are likely to be independent of each other and are partly dependent on the cells that are treated with IFN- $\alpha(3,4)$. In particular, IFN- $\alpha$ has been shown to induce autophagy (5).

\section{Materials and methods}

Cell culture. The human osteosarcoma MG-63 cell line was obtained from the American type culture collection (Manassas, VA, USA). The MG-63 cells were propagated in Dulbecco's modified Eagle medium (Gibco, Carlsbad, CA, USA) supplemented with $10 \%$ fetal bovine serum (Gibco) and antibiotics in a humidified incubator containing $5 \% \mathrm{CO}_{2}$ at $37^{\circ} \mathrm{C}$. Human IFN- $\alpha$ (Sigma-Aldrich, St Louis, MO, USA) was diluted in serum-free medium.

Matrigel invasion assay. The Matrigel invasion assay was performed to assess the effects of IFN- $\alpha$ on the invasive properties of the MG-63 cells. Transwell inserts (12-well, 12-mm with $12.0-\mu \mathrm{m}$ pore size) from Corning Inc. (Corning, NY, USA) were coated with $200 \mu$ l Matrigel (final concentration, $1.0 \mathrm{mg} / \mathrm{ml}$ in ice-cold serum-free medium; BD Biosciences, San Jose, CA, USA) and allowed to dry at $37^{\circ} \mathrm{C}$ for $3-5 \mathrm{~h}$. The cells were treated for $48 \mathrm{~h}$ with IFN- $\alpha$ at concentrations of $1 \times 10^{2}, 1 \times 10^{3}$ or $1 \times 10^{4} \mathrm{IU} / \mathrm{ml}$. The control and treated cells were washed twice with serum-free medium and trypsinized. A $200-\mu 1$ cell suspension $\left(2 \times 10^{5}\right.$ cells) from each sample was added to each well in triplicate.

The filters were incubated for $48 \mathrm{~h}$ at $37^{\circ} \mathrm{C}$ in a humidified incubator containing $5 \% \mathrm{CO}_{2}$, fixed and stained with $0.5 \%$ crystal violet in methanol. The non-migratory cells were removed with a cotton tip and the migratory cells were counted using a light microscope (Olympus, Tokyo, Japan) at x400 magnification. Each experiment was run in duplicate. The results are expressed as the mean number of cells that were counted in each field, \pm standard deviation (SD). 
A

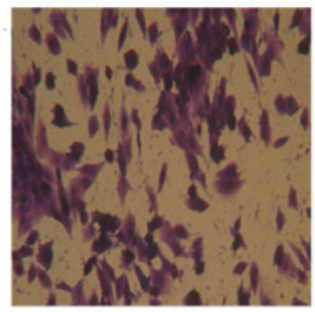

Control

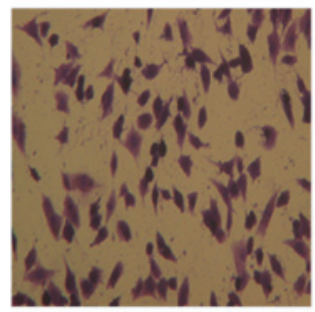

$1000 \mathrm{IU} / \mathrm{ml}$ IFN- $\alpha$

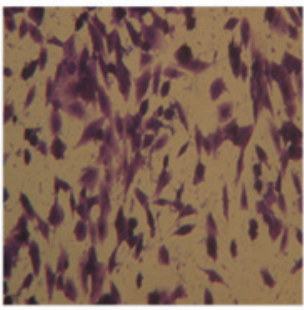

$10 \mathrm{IU} / \mathrm{ml}$ IFN- $\alpha$

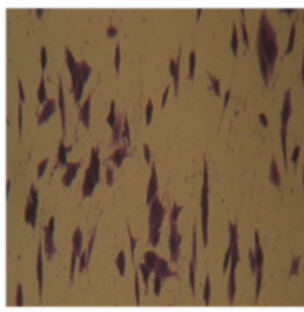

$10000 \mathrm{IU} / \mathrm{ml} \mathrm{IFN- \alpha}$

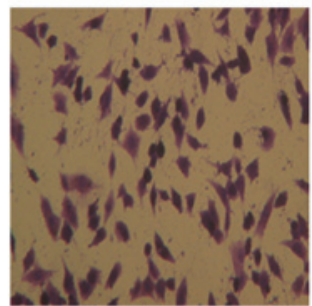

$100 \mathrm{IU} / \mathrm{ml}$ IFN- $\alpha$

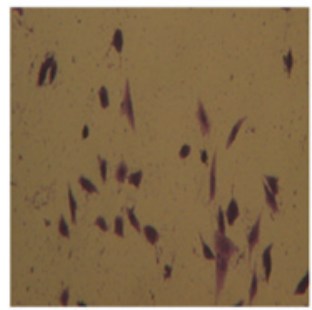

$100000 \mathrm{IU} / \mathrm{ml}$ IFN- $\alpha$

B

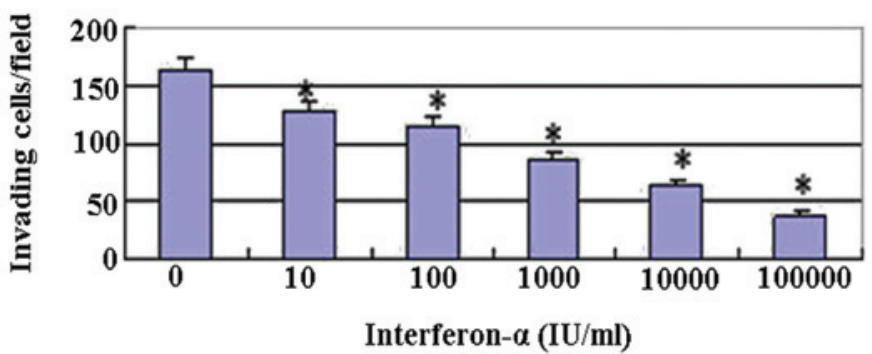

Figure 1. Cell invasion assay following treatment with IFN- $\alpha$ for $48 \mathrm{~h}$. (A) Representative cell invasion assay for the MG-63 cells. The invasion assays were performed in 12-well Transwell inserts of polycarbonate filters with $12.0-\mu \mathrm{m}$ pores that were coated with $200 \mu \mathrm{l} 0.1 \%$ Matrigel. Following a 48 -h incubation period, the membranes were collected and stained. A significant reduction in the number of invaded cells indicated a decrease in the invasive capacity (magnification, x400). (B) Quantitative evaluation of the Matrigel invasion assay. The data are presented as the mean \pm SD of 10 randomly selected microscopic fields from three independent wells $\left({ }^{*} \mathrm{P}<0.01\right.$, compared with the control mean values). IFN, interferon.

Cell proliferation assay. For the assessment of the cell growth, the MG-63 cells (5,000 cells/well) were treated with various concentrations of IFN- $\alpha$ and cisplatin in 96-well plates. At $48 \mathrm{~h}$ post-treatment, the cell growth was evaluated using a 3-(4,5-dimethylthiazol-2-yl)-2,5-diphenyltetrazolium bromide (MTT) assay. MTT (Sigma-Aldrich) was added to the culture medium in each well at a concentration of $500 \mu \mathrm{g} / \mathrm{ml}$. Following incubation for $4 \mathrm{~h}$ at $37^{\circ} \mathrm{C}, 100 \mu \mathrm{l}$ dimethyl sulfoxide (DMSO) was added to each well and the 550-nm absorption was measured. Each experiment was reproduced in six wells and repeated at least three times.

Hoechst 33258 staining. The MG-63 cells were treated with various concentrations of IFN- $\alpha$ and cisplatin in six-well plates. At $48 \mathrm{~h}$ post-treatment, the cells were washed in cold phosphate-buffered saline twice and fixed in $4 \%$ formaldehyde at $4^{\circ} \mathrm{C}$ for $10 \mathrm{~min}$. Following this, the fixed cells were washed and labeled with $5 \mu \mathrm{g} / \mathrm{ml}$ Hoechst 33258 (Sigma-Aldrich), and maintained at room temperature in the dark for $10 \mathrm{~min}$. The cells were then observed and imaged using a fluorescence microscope (Olympus) with excitation at $350 \mathrm{~nm}$ and emission at $460 \mathrm{~nm}$. Apoptosis of the MG-63 cells was determined by the alteration of nuclear morphology and fluorescent density that was observed subsequent to staining the cells with Hoechst 33258.

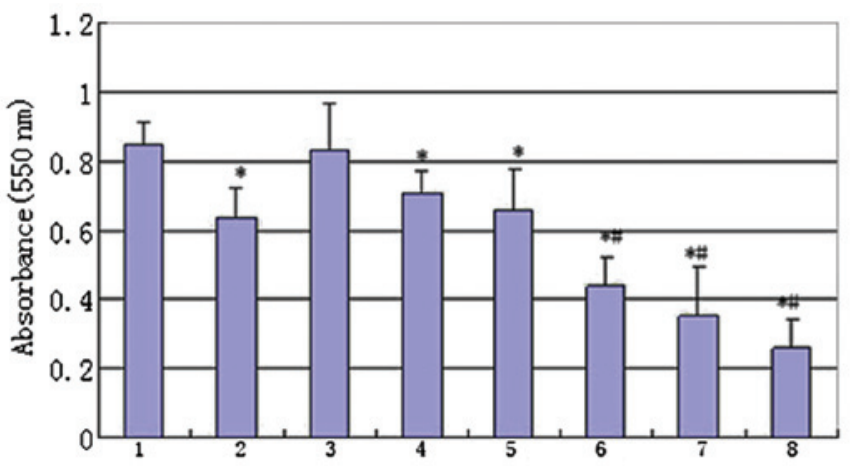

Figure 2. Antiproliferative effect of IFN- $\alpha$ and cisplatin. The MG-63 cells were treated with IFN- $\alpha$ and/or cisplatin. The cell viability was determined by an MTT assay. Group 1, control; 2, treated with $5 \mu \mathrm{g} / \mathrm{ml}$ cisplatin; 3, treated with $100 \mathrm{IU} / \mathrm{ml} \mathrm{IFN}-\alpha ; 4$, treated with $1,000 \mathrm{IU} / \mathrm{ml} \mathrm{IFN-} \alpha$; 5 , treated with $10,000 \mathrm{IU} / \mathrm{ml} \mathrm{IFN-} \alpha ; 6$, combination therapy of $100 \mathrm{IU} / \mathrm{ml} \mathrm{IFN}-\alpha$ and $5 \mu \mathrm{g} / \mathrm{ml}$ cisplatin; 7, combination therapy of $1,000 \mathrm{IU} / \mathrm{ml} \mathrm{IFN}-\alpha$ and $5 \mu \mathrm{g} / \mathrm{ml}$ cisplatin and 8 , combination therapy of $10,000 \mathrm{IU} / \mathrm{ml} \mathrm{IFN}-\alpha$ and $5 \mu \mathrm{g} / \mathrm{ml}$ cisplatin. $\left({ }^{*} \mathrm{P}<0.01\right.$, compared with the control mean values and ${ }^{\#} \mathrm{P}<0.01$ compared with group 2 mean values). IFN, interferon; MTT, 3-(4,5-dimethylthiazol-2-yl)-2,5-diphenyltetrazolium bromide.

Annexin V-fluorescein isothiocyanate (FITC)/propidium iodide (PI) double labeling for flow cytometry (FCM)-assessed apoptosis. An Annexin V-FITC kit (BD Biosciences) was 


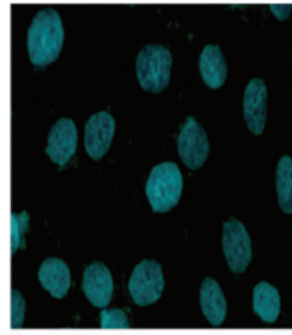

Control

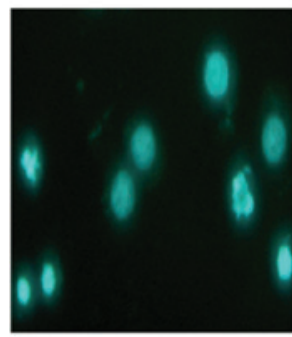

$10000 \mathrm{IU} / \mathrm{ml}$ IFN-

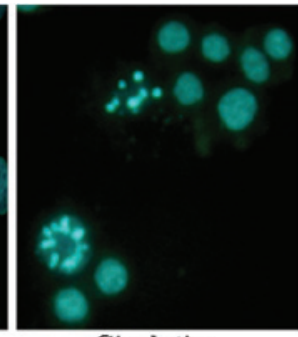

Cisplatin

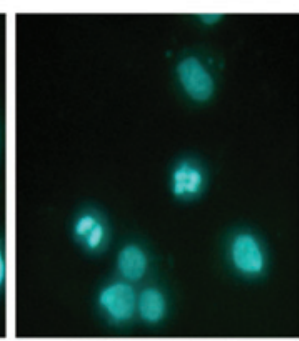

$100 \mathrm{IU} / \mathrm{ml} \mathrm{IFN- \alpha}$ + cisplatin

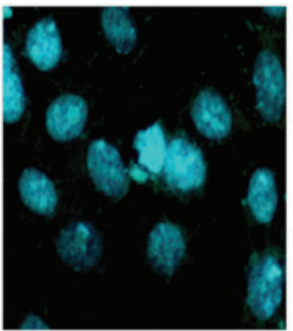

$100 \mathrm{IU} / \mathrm{ml}$ IFN- $\alpha$

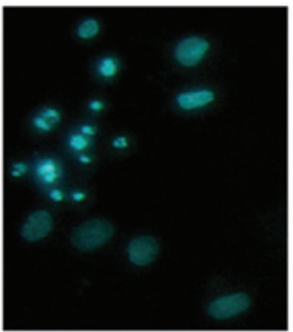

$1000 \mathrm{IU} / \mathrm{ml}$ IFN- $\alpha$ +cisplatin

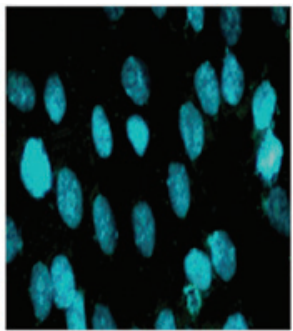

$1000 \mathrm{IU} / \mathrm{ml}$ IFN- $\alpha$

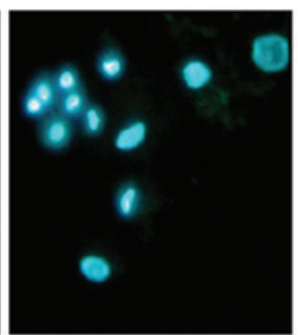

$10000 \mathrm{IU} / \mathrm{ml} \mathrm{IFN}-\alpha$ +cisplatin

Figure 3. Hoechst 33258 staining to detect the of apoptosis of MG-63 cells induced by IFN- $\alpha$ and/or cisplatin. The MG-63 cells were incubated with various concentrations of IFN- $\alpha$ and/or cisplatin for $48 \mathrm{~h}$ prior to being stained with Hoechst 33258 (magnification, x400). IFN, interferon.

A

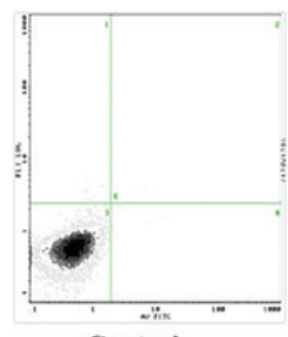

Control

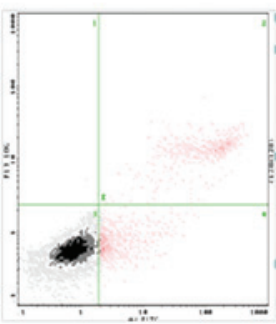

$10000 \mathrm{IL}^{-} / \mathrm{ml}$ IFN- $\alpha$

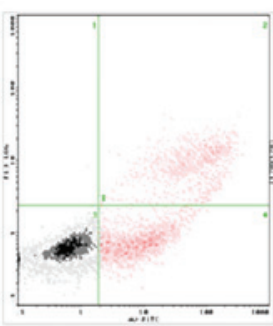

Cisplatin

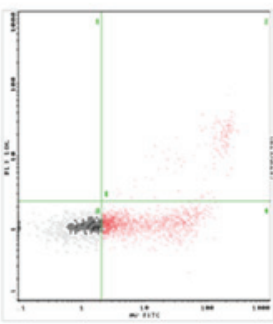

$100 \mathrm{IC} / \mathrm{ml} \mathrm{IFY-co}$ + cisplatin

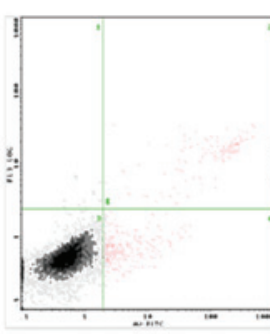

$100 \mathrm{IL}^{-} / \mathrm{ml}$ IFN- $\alpha$

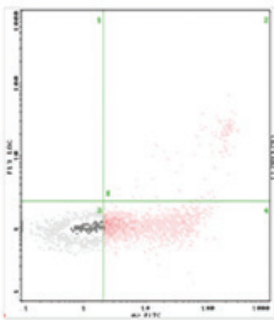

$1000 \mathrm{IL} / \mathrm{ml}$ IFN $-\alpha$ +cisplatin
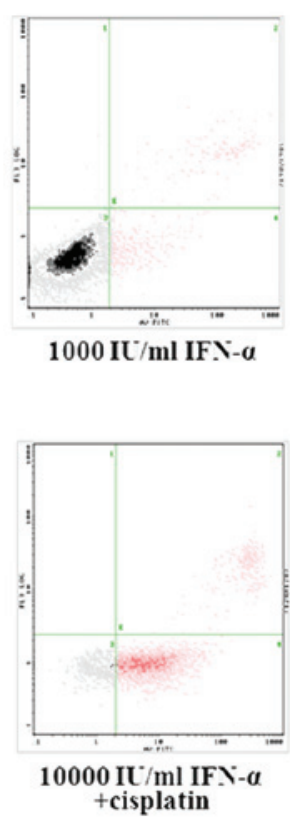

B

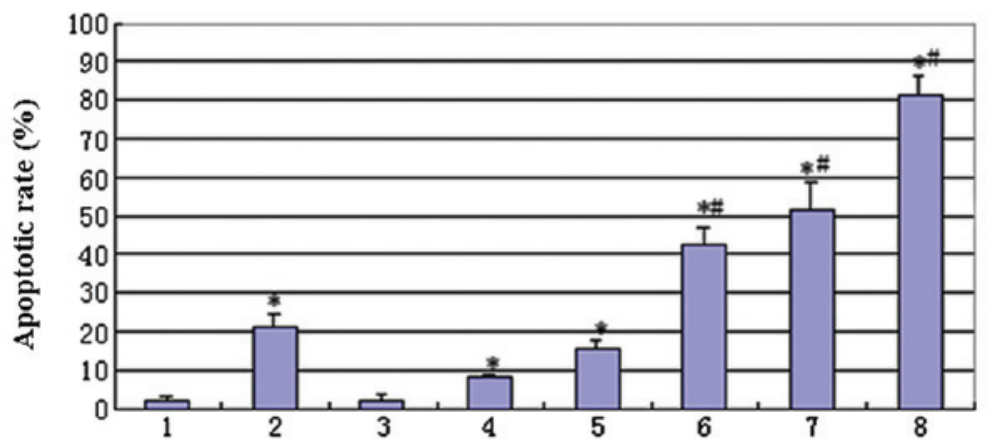

Figure 4. (A) Annexin V and PI staining for FACS detection of apoptosis of MG-63 cells induced by IFN- $\alpha$ and/or cisplatin. The MG-63 cells were incubated with various concentrations of IFN- $\alpha$ and/or cisplatin for $48 \mathrm{~h}$ prior to being stained with Annexin V and PI. (B) Quantitative evaluation of the FACS assay. Group 1, control; 2 , treated with $5 \mu \mathrm{g} / \mathrm{ml}$ cisplatin; 3 , treated with $100 \mathrm{IU} / \mathrm{ml}$ IFN- $\alpha ; 4$, treated with 1,000 IU/ml IFN- $\alpha ; 5$, treated with 10,000 IU/ml IFN- $\alpha ; 6$, combination therapy of $100 \mathrm{IU} / \mathrm{ml} \mathrm{IFN}-\alpha$ and $5 \mu \mathrm{g} / \mathrm{ml}$ cisplatin; 7 , combination therapy of $1,000 \mathrm{IU} / \mathrm{ml} \mathrm{IFN}-\alpha$ and $5 \mu \mathrm{g} / \mathrm{ml}$ cisplatin and 8 , combination therapy of $10,000 \mathrm{IU} / \mathrm{ml} \mathrm{IFN}-\alpha$ and $5 \mu \mathrm{g} / \mathrm{ml}$ cisplatin. ( $\mathrm{P}<0.01$, compared with the control mean values and ${ }^{\#} \mathrm{P}<0.01$, compared with treated with group 2 mean values). PI, propidium iodide; FACS, fluorescence-activated cell sorting; IFN, interferon. 


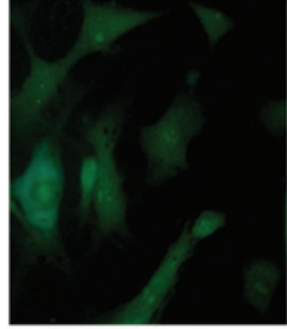

Control

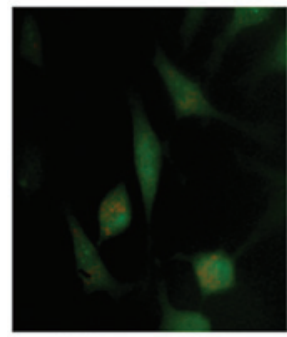

$10000 \mathrm{IU} / \mathrm{ml} \mathrm{IFN}-\alpha$

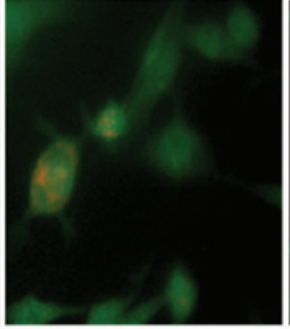

Cisplatin

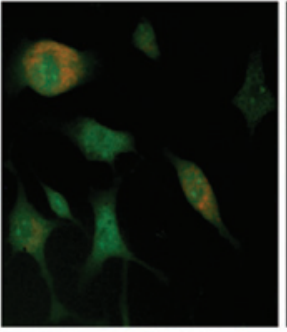

$100 \mathrm{IU} / \mathrm{ml}$ IFN- $\alpha$ +cisplatin

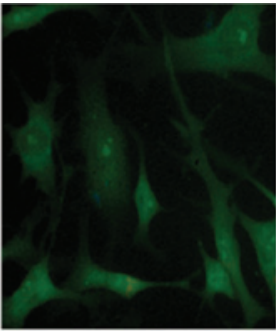

$100 \mathrm{IU} / \mathrm{ml} \mathrm{IFN- \alpha}$

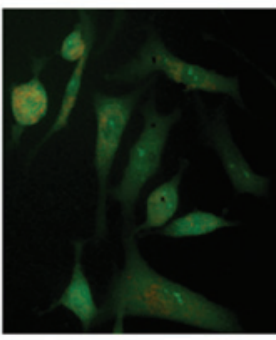

$1000 \mathrm{IU} / \mathrm{ml}$ IFN- $\alpha$ + cisplatin

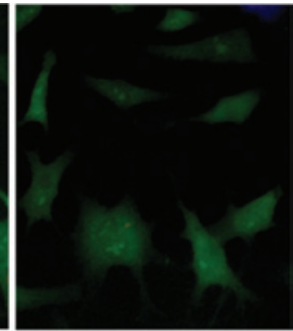

$1000 \mathrm{IU} / \mathrm{ml}$ IFN- $\alpha$

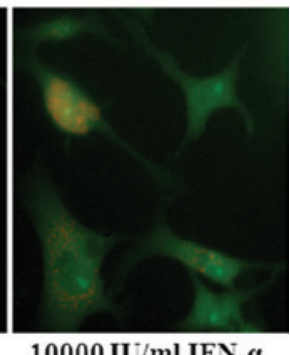

$10000 \mathrm{IU} / \mathrm{ml}$ IFN- $\alpha$ +cisplatin

Figure 5. Acridine orange staining for autophagy. The cells were grown on coverslips, treated with IFN- $\alpha$ and/or cisplatin for $48 \mathrm{~h}$ and then stained with acridine orange. Autophagic vacuoles were observed and imaged using a fluorescence microscope (magnification, x400). IFN, interferon.

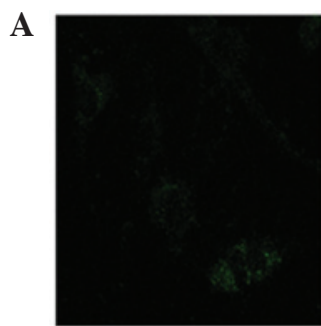

Control

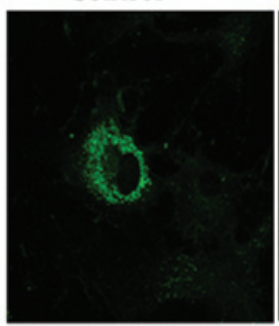

$10000 \mathrm{IL} / \mathrm{ml}$ IFV゙- $\bullet$

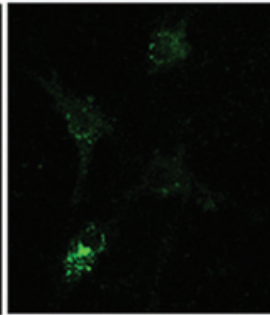

Cisplatin

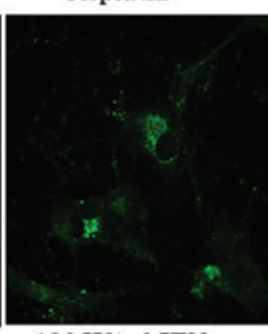

$100 \mathrm{IL} / \mathrm{ml} \mathrm{IFN-}$ +cisplatin

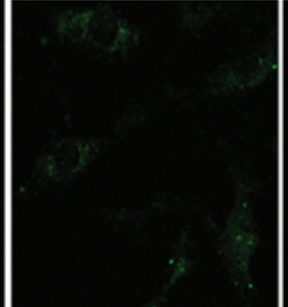

$100 \mathrm{IC}^{-} / \mathrm{ml}$ IFN- $\alpha$
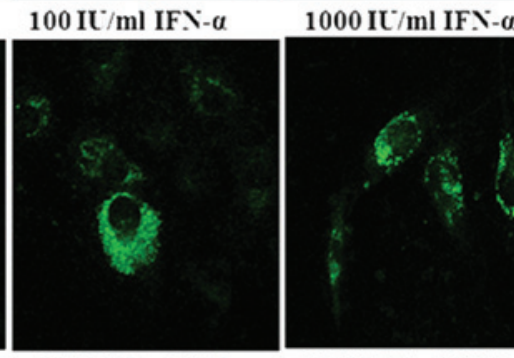

B

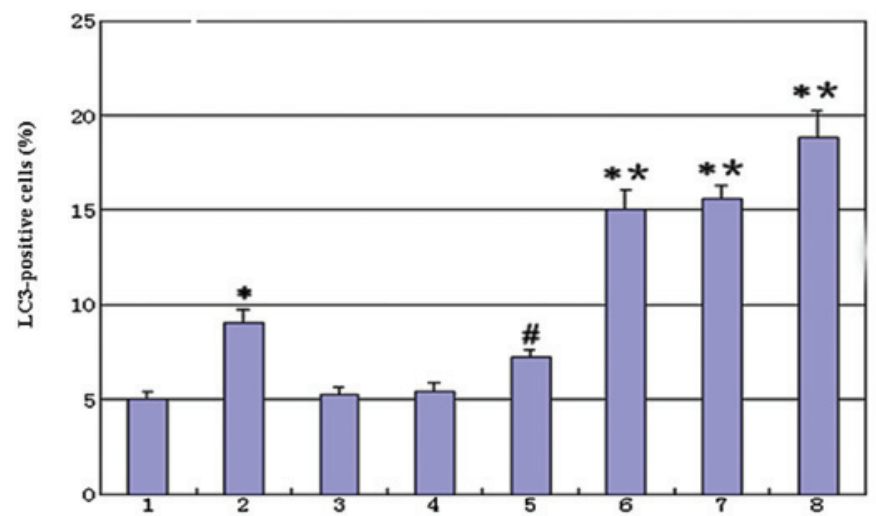

Figure 6. (A) IFN- $\alpha$ and/or cisplatin induced punctuated GFP-LC3 distribution in cells. At $24 \mathrm{~h}$ following the transient transfection of GFP-LC3, the cells were treated with IFN- $\alpha$ and/or cisplatin for $48 \mathrm{~h}$ and analyzed for fluorescence. The images were captured using a fluorescence microscope (magnification, $\mathrm{x} 400$ ). (B) Quantitative assay: The induction of autophagy was quantified by counting the percentage of cells in each group that contained LC3 aggregates.

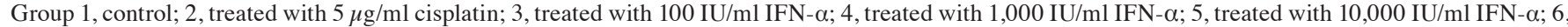
combination therapy of $100 \mathrm{IU} / \mathrm{ml} \mathrm{IFN}-\alpha$ and $5 \mu \mathrm{g} / \mathrm{ml}$ cisplatin; 7, combination therapy of $1,000 \mathrm{IU} / \mathrm{ml} \mathrm{IFN}-\alpha$ and $5 \mu \mathrm{g} / \mathrm{ml}$ cisplatin and 8 , combination therapy of $10,000 \mathrm{IU} / \mathrm{ml} \mathrm{IFN}-\alpha$ and $5 \mu \mathrm{g} / \mathrm{ml}$ cisplatin. (" $\mathrm{P}<0.01$, compared with the control mean values; ${ }^{\sharp} \mathrm{P}<0.05$, compared with the control mean values and ${ }^{*} \mathrm{P}<0.01$, compared with group 2 mean values). IFN, interferon; GFP, green fluorescence protein. 


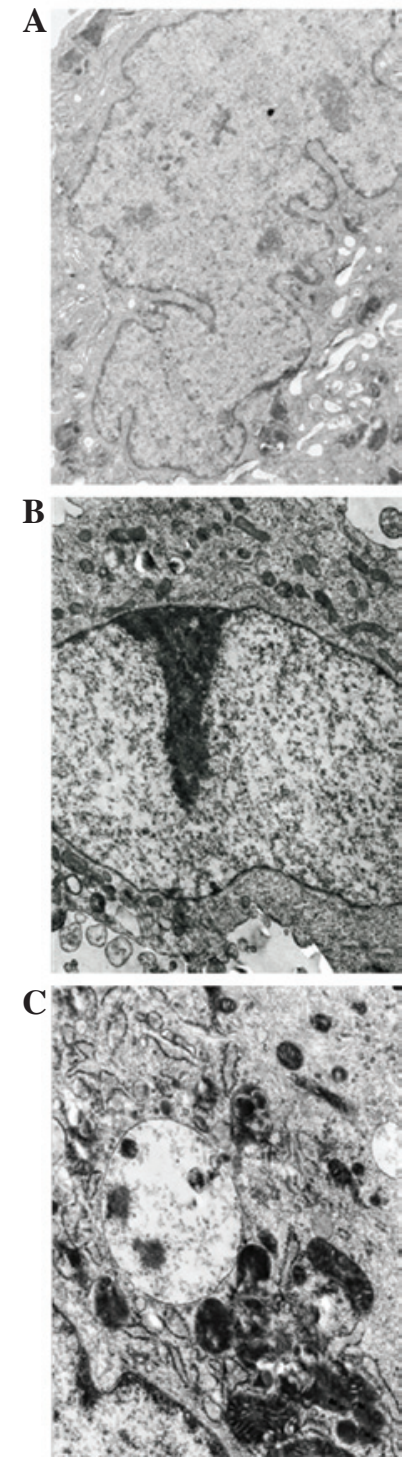

Figure 7. Transmission electron images of MG-63 cells that were treated with IFN- $\alpha$ and/or cisplatin. (A) Control group. (B) Combination therapy of $10,000 \mathrm{IU} / \mathrm{ml} \mathrm{IFN}-\alpha$ and $5 \mu \mathrm{g} / \mathrm{ml}$ cisplatin (group 8), chromatin margination and appearance of crescent-shaped chromatin. (C) Combination therapy of $10,000 \mathrm{IU} / \mathrm{ml} \mathrm{IFN-} \alpha$ and $5 \mu \mathrm{g} / \mathrm{ml}$ cisplatin (group 8). The arrow head indicates the single- and double-membrane vesicles containing intact and degraded cellular debris (magnification, x6,000). IFN, interferon.

used to detect apoptosis. The cells were cultured with various concentrations of IFN- $\alpha$ and cisplatin for $48 \mathrm{~h}$, harvested through trypsinization and washed twice. The cells were then reacted with FITC-conjugated Annexin V and PI for $15 \mathrm{~min}$. The staining profiles were determined using FACScan (BD Biosciences, Franklin Lakes, NJ, USA) and Cell-Quest software (BD Biosciences). The early apoptotic cells (Annexin-FITC-positive and PI-negative) were located in the lower right quadrant. The late apoptotic or necrotic cells (Annexin-FITC-positive and PI-positive) were located in the upper right quadrant. The healthy cells (negative for the two probes) were located in the lower left quadrant. The results are expressed as the percentage of positively-stained cells among total cells. Each group was repeatedly measured six times and each sample included $1 \times 10^{4}$ cells.
Acridine orange staining for autophagy. Autophagy is characterized by the formation and promotion of acidic vesicular organelles. The MG-63 cells were treated with various concentrations of IFN- $\alpha$ and cisplatin in six-well plates. At $48 \mathrm{~h}$ post-treatment, the cells were incubated with $1 \mathrm{mg} / \mathrm{ml}$ acridine orange (Sigma-Aldrich) for $15 \mathrm{~min}$. Images were obtained using a fluorescence microscope.

Green fluorescent protein (GFP)-LC3 dot assay. The cells were transiently transfected with a GFP-LC3 (Origene Tech., Inc., Rockville, MD, USA) vector using Lipofectamine LTX and PLUS Reagents (Invitrogen Life Technologies, Carlsbad, CA, USA) according to the manufacturer's instructions. After $24 \mathrm{~h}$, the cells were exposed to IFN- $\alpha$ and/or cisplatin for $48 \mathrm{~h}$ as indicated and examined under a fluorescence microscope. The induction of autophagy was quantified by counting the percentage of cells in each group that contained LC3 aggregates.

Transmission electron microscopy. The cells were fixed with $3 \%$ glutaraldehyde in a 0.1-M cacodylate buffer for $1 \mathrm{~h}$. Following fixation, the samples were post-fixed in $1 \% \mathrm{OsO}_{4}$ in the same buffer for $30 \mathrm{~min}$. Ultra-thin sections were then observed under a transmission electron microscope (JEOL, Tokyo, Japan).

Statistical analysis. The experimental data are expressed as the mean \pm SD. The group means were compared using a t-test via the statistical software program, SPSS 13.0 (SPSS, Inc., Chicago, IL, USA). $\mathrm{P}<0.05$ was considered to indicate a statistically significant difference.

\section{Results}

IFN- $\alpha$ markedly reduces tumor cell invasion in MG-63 cells. Cell invasion was evaluated following the treatment (Fig. 1). Marked reductions in the invasive properties of the MG-63 cells were observed following the treatment with IFN- $\alpha$ alone through the Matrigel invasion assays. The staining of the invaded cells through the membrane demonstrated that the number of invasive cells was significantly reduced in the cells that were treated with IFN- $\alpha$ alone, compared with that of the untreated control cells.

Anti-proliferative effects of IFN- $\alpha$ and/or cisplatin in $M G$ - 63 cells. The effect of adding a low (100 IU/ml), middle $(1,000 \mathrm{IU} / \mathrm{ml})$ or high $(10,000 \mathrm{IU} / \mathrm{ml})$ dose of IFN- $\alpha$ on the antiproliferative activity of cisplatin was investigated. As shown in Fig. 2, cell proliferation was inhibited by exposing the cells to $100,1,000$ or $10,000 \mathrm{IU} / \mathrm{ml} \mathrm{IFN-} \alpha$ and $/$ or $5 \mu \mathrm{g} / \mathrm{ml}$ cisplatin for 48 h. Cells treated with a combination of IFN- $\alpha$ and cisplatin exhibited more potent antiproliferative activity compared with those treated with cisplatin alone, in a dose-dependent manner.

Effect of IFN- $\alpha$ and/or cisplatin on apoptosis in MG-63 cells. The effect of adding a low $(100 \mathrm{IU} / \mathrm{ml})$, middle $(1,000 \mathrm{IU} / \mathrm{ml})$ or high $(10,000 \mathrm{IU} / \mathrm{ml})$ dose of IFN- $\alpha$ on the apoptotic action of cisplatin was investigated. The typical apoptotic morphological changes, including condensed chromatin and 
shrunken, crumpled and condensed nuclei, were observed in the MG-63 cells that were treated with IFN- $\alpha$ and cisplatin following staining with Hoechst 33258 (Fig. 3). A quantitative determination of MG-63 cell apoptosis that was induced by IFN- $\alpha$ and/or cisplatin was performed using Annexin V and PI staining. The cisplatin-mediated apoptosis effect, which was enhanced by IFN- $\alpha$, was dose-dependent. The most evident apoptosis effect occurred following the addition of a high dose (10,000 IU/ml) of IFN- $\alpha$ and $5 \mu \mathrm{g} / \mathrm{ml}$ cisplatin (Fig. 4A). The quantitative results are shown in Fig. 4B.

Effect of IFN- $\alpha$ and/or cisplatin on autophagy in MG-63 cells. Following treatment with cisplatin or high-dose $(10,000 \mathrm{IU} / \mathrm{ml})$ IFN- $\alpha$, the cells revealed an intracellular accumulation of acidic vesicular and autolysosomes, implying that cisplatin or a high-dose of IFN- $\alpha$ may induce autophagic responses. Co-treatment with IFN- $\alpha$ increased the cisplatin-induced acidic vesicular in the MG-63 cells. (Fig. 5). GFP-LC3 exhibited a diffuse pattern, which became punctuated when treated with cisplatin. Co-treatment with IFN- $\alpha$ increased the cisplatin-induced punctuated pattern in the MG- 63 cells and the cisplatin-mediated autophagy effects were enhanced by IFN- $\alpha$ in a dose-dependent manner (Fig. 6A). The quantitative results are shown in Fig. 6B. Additionally, the co-treatment of IFN- $\alpha$ and cisplatin for $48 \mathrm{~h}$ developed autophagosome-like characteristics, including single- and double-membrane vacuoles containing intact and degraded cellular debris (Fig. 7). These data confirmed that the co-treatment with IFN- $\alpha$ increased cisplatin-induced autophagy in the MG-63 cells.

\section{Discussion}

Osteosarcoma is the most common primary tumor of the bone and predominantly occurs in the second decade of life. The condition is the most frequently occurring pediatric non-hematological tumor of the bone and the fifth most prevalent malignancy of adolescence (6). Osteosarcoma is notable for locally aggressive behavior and early metastasis formation. High-dose cytotoxic chemotherapy and surgical resection have improved the prognosis of patients with osteosarcoma. The long-term survival for patients with localized (non-metastatic) disease is $\sim 70 \%$, but at the cost of considerable therapy-related morbidity $(7,8)$. At present, $\sim 20 \%$ of patients have metastases and almost all patients with recurrent osteosarcoma have metastatic disease. The cure rate for patients with metastatic or recurrent disease remains poor $(9,10)$. Effective post-operative adjuvant therapies, therefore, are extremely significant for improving the overall survival of osteosarcoma patients.

IFN- $\alpha$ is a cytokine that belongs to type I IFNs and exerts multiple effects on cellular functions $(1,11,12)$. The IFN- $\alpha$ family is composed of at least 13 functional IFN subtypes, which share the same receptor system and exert similar biological activities $(13,14)$. In particular, 50 years of research on IFN- $\alpha$ have revealed that these cytokines exhibit a variety of biological effects, which differ from those that are present during viral replication, including antitumor activity. IFN- $\alpha$ is a widely expressed cytokine that is secreted as the first line of defense against several tumors (15). It has been used in $>40$ countries for the treatment of $>14$ types of cancer, including certain hematological malignancies (hairy cell leukemia, chronic myeloid leukemia and certain B- and T-cell lymphomas) and certain solid tumors, including melanoma, renal carcinoma and Kaposi's sarcoma. However, despite numerous years of intense work in animal tumor models and considerable experience in the clinical use of IFN- $\alpha$, the significance of the various mechanisms of action underlying the response in patients remains a matter of debate. It was previously considered that the direct inhibitory effects on tumor cell growth were the main mechanisms that were significant in the antitumor response in IFN-treated patients. However, it has been shown that IFN- $\alpha$ is able to directly inhibit the proliferation of normal and tumor cells in vitro and in vivo, and may exert other direct effects on tumor cells $(16,17,18)$.

The present study on human osteosarcoma MG-63 cells demonstrated that IFN- $\alpha$ treatment suppressed human osteosarcoma cell invasion. The Matrigel invasion assays demonstrated marked reductions in the invasive properties of the MG-63 cells following treatment with IFN- $\alpha$. The osteosarcoma cells were also treated with cisplatin and/or IFN- $\alpha$. Apoptosis and autophagy were assessed using MTT assay, Hoechest 33258 staining, FCM assay, acridine orange staining, GFP-LC3 dotted assay and transmission electron microscopy. Further analysis demonstrated that the effects of cisplatin may be enhanced by combining the drug with IFN- $\alpha$.

In conclusion, the present study has shown that IFN- $\alpha$ is able to suppress invasion and enhance cisplatin-mediated apoptosis and autophagy in human osteosarcoma MG-63 cells. The combination therapy of chemotherapeutics and IFN- $\alpha$ may be a novel approach for osteosarcoma, and further evidence is required by experiments in vivo.

\section{Acknowledgements}

This study was supported by grants from the Scientific Support Project of the Anhui Provincial Education Department of China (nos. KJ2012ZD08 and KJ2012Z162), the National Scientific and Technological Support Projects of China (no.81101273), the Key Basic Research and Development Program of China (973; no.2007CB513108) and the National Natural Science Foundation of China (no. 30872253).

\section{References}

1. Zhang W, Rao HY, Feng B, Liu F and Wei L: Effects of interferon-alpha treatment on the incidence of hyperglycemia in chronic hepatitis $\mathrm{C}$ patients: a systematic review and meta-analysis. PLoS One7: e39272, 2012.

2. Tough DF: Modulation of T-cell function by type I interferon. Immunol Cell Biol 90: 492-497, 2012

3. Yim HY, Yang Y, Lim JS, Lee MS, Zhang DE and Kim KI: The mitochondrial pathway and reactive oxygen species are critical contributors to interferon- $\alpha / \beta$-mediated apoptosis in Ubp43-deficient hematopoietic cells. Biochem Biophys Res Commun 423: 436-440, 2012.

4. Fishman AI, Johnson B, Alexander B, Won J, Choudhury M and Konno S: Additively enhanced antiproliferative effect of interferon combined with proanthocyanidin on bladder cancer cells. J Cancer 3: 107-112, 2012.

5. Harris J: Autophagy and cytokines. Cytokine 56: 140-144, 2011.

6. Ottaviani $G$ and Jaffe N: The epidemiology of osteosarcoma. Cancer Treat Res 152: 3-13, 2009.

7. Anninga JK, Gelderblom H, Fiocco M, Kroep JR, Taminiau AH, Hogendoorn PC and Egeler RM: Chemotherapeutic adjuvant treatment for osteosarcoma: where do we stand? Eur J Cancer 47: 2431-2445, 2011 
8. Dai X, Ma W, He X and Jha RK: Review of therapeutic strategies for osteosarcoma, chondrosarcoma, and Ewing's sarcoma. Med Sci Monit 17: 177-190, 2011.

9. Loeb DM: Is there a role for immunotherapy in osteosarcoma? Cancer Treat Res 152: 447-457, 2009.

10. Jaffe N: Osteosarcoma: review of the past, impact on the future. The American experience, Cancer Treat Res 152: 239-262, 2009

11. Tarhini AA, Gogas H and Kirkwood JM: IFN- $\alpha$ in the treatment of melanoma. J Immunol 189: 3789-3793, 2012.

12. Pasquali S and Mocellin S: The anticancer face of interferon alpha (IFN-alpha): from biology to clinical results, with a focus on melanoma. Curr Med Chem 17: 3327-3336, 2010.

13. Moll HP, Maier T, Zommer A, Lavoie T and Brostjan C: The differential activity of interferon- $\alpha$ subtypes is consistent among distinct target genes and cell types. Cytokine 53: 52-59, 2011

14. Miwa S, Kadono Y, Sugata T, Mizokami A and Namiki M: Successful treatment for metastases from renal cell carcinoma with alternation of interferon-alpha subtypes. Int J Clin Oncol 15 97-100 2010
15. Mahmutović $\mathrm{S}$ and Beslagić E: Significance of the interferon (IFN) in the therapy. Bosn J Basic Med Sci 4: 42-44, 2004.

16. de Vries-van Leeuwen IJ, Kortekaas-Thijssen C, Nzigou Mandouckou JA, Kas S, Evidente A and de Boer AH: Fusicoccin-A selectively induces apoptosis in tumor cells after interferon-alpha priming. Cancer Lett 293: 198-206, 2010.

17. Ota K, Matsumiya T, Sakuraba H, Imaizumi T, Yoshida H, Kawaguchi S, Fukuda S and Satoh K: Interferon-alpha2b induces p21cip1/waf1 degradation and cell proliferation in HeLa cells Cell Cycle 9: 131-139, 2010.

18. Zhang T, Sun HC, Zhou HY, Luo JT, Zhang BL, Wang P, Wang L, Qin LX, Ren N, Ye SL, et al: Interferon alpha inhibits hepatocellular carcinoma growth through inducing apoptosis and interfering with adhesion of tumor endothelial cells. Cancer Lett 290: 204-210, 2010 